in the quarry at Shap summit, near the Granite works, which is said to be the same Limestone, though there are frequent vegetable remains (Stigmaria, etc.) in that quarry.

Professor Garwood, in his provisional correlation of the Faunal Succession in the Carboniferous Limestone of these Northern exposures, ${ }^{1}$ places the Meathop Fell Beds doubtfully in $\mathrm{C}_{1}$, and correlates them with similar dolomitic beds at Crag Mollet in the Brigsteer section. At the latter place a bed occurs at the base which is marked by clusters of Diphyphyllum pseudo-vermiculare ( $\left.\mathrm{H}^{\circ} \mathrm{Coy}\right)$. This same form also occurs abundantly near the top of the Shap-Ravenstonedale Limestone, so that the beds containing $A$. Vanuxemi at Shap are, in all probability, equicalent to the 'Vanuxemi Beds' at Meathop Fell.

Professor Garwood further remarks on the possibility of the above Diphyphrllid Lithostrotion being considered typical of (S), in which case the Meathop Fell Beds, and others, would have to be included in (S) also.

The discorery, therefore, of $A$. Famuxemi at Meathop Fell, coupled with its occurrence in beds of, presumably, the same age at Shap, may be helpful in arriving at a satisfactory conclusion as to the correct horizon of these beds, especially when the exact horizon of the plant is known in the North Wales exposure.

In conclusion, I must express my indebtedness to Mr. J. T. Stobbs, F.G.S., and Dr. 'T. F. Sibly, F.G.S., etc., for their kindness in confirming the identification of several specimens, and to Dr. $R$. Kidston, F.R.S., etc., for kindly looking orer the plant-remains and giving me his opinion thereon.

\title{
MOTIOES OF MEMOIRS.
}

Note on the Spontaneots Luminosity of a Uraniom Mineral. By the Hon. R. J. Srrutr, M.A., F.R.S., Professor of Physics, Imperial College of Science, South Kensington.

$\mathrm{R}$ UMOURS of luminosity having been observed in Cornish minerals, $B$ in the dark, are not infrequent. I have myself been told of such phenomena by rustics in the mining district, and more than one correspondent has mentioned something similar.

Mr. F. W. Rudler ${ }^{3}$ has quoted a remark by the late Mr. Garby that specimens of uranite "when first discovered by the miners in Huel Buller and Huel Basset were very phosphorescent, so much so that after the lights were extinguished many of the crystals might be discorered in situ ", ${ }^{4}$ and he has suggested that this may be in some way connected with the self-luminosity of radio-active bodies. The observation would scem to have been made by the miners, not by a scientific observer, and it is implied that the luminosity was of the nature of ordinary phosphorescence, and due to previous exposure to light.

1 Geol. MaG., 1907, p. 70.

2 Proc. Rov. Soc., Series A, 1909, vol. Ixxxiii, p. 70. (Abridged.

3 Handbook to Ifinerals of the Britivh IN/ands, published by the Geologieal Survey.

- Trans. Roy. Geol. Soc. Cornwall, 186.5, vol. vii, p. 86. 
Recently examining a specimen of uranite (autunite), I was struck by its resemblance to the artificially prepared uranium salts, and it occurred to me that in all probability it would be found to exhibit the spontaneous Iuminosity observed in these by $\mathbf{H}$. Becquerel, ${ }^{1}$ which is attributable to fluorescence of the substance under the action of its own radio-activity. Experiment confirmed this anticipation. The mineral is easily perceived in a perfectly dark room by a well-rested eye. There is no difficulty in walking up to it from a distance and touching it, without any other guidance than the luminosity. Autunite is more luminous than uranium nitrate, but.less so than potassium uranyl sulphate.

This effect is quite independent of the previous exposure to light. Such exposure only leaves an afterglow in uranium salts of very short duration. It cannot be detected without the phosphoroscope.

The specimens in which I have observed the luminosity are some. recently raised in Portugal, which I owe to the kindness of Mr. A. de. Vere Hunt. Old specimens from Cornwall and from Autun do not exhibit it. The loss of luminosity is connected with a loss of water of crystallization. This was established experimentally by sealing up a specimen in an exhausted glass tube with phosphoric anhydride. In a few hours the latter had deliquesced considerably, while the autunite had lost both its luminosity in the dark, and also the green fluorescent shimmer which it had previously exhibited in daylight. Some uranium salts are known to be much more fluorescent than others, and there is nothing specially surprising in the fact that a losi of water is accompanied by a loss of brilliancy.

\section{REVIEWS.}

\section{I.-Geologicat Sufvey of Great Brttix.}

The Grodogy of the Country around Basingstomb BJ $H$. J. Osborne White, F.G.S. pp. v, 119 , with 14 text-illustrations. 1909. Price 2s. Colour-printed map, Sheet 284, 1s. 6d.

A LTHOUGH not officially connected with the Geological Survey, A Mr. Osborne White has already rendered much service to the Institution in writing the Memoir on the Geology of Hungerford and Newbury, and in assisting with those on Andorer, Henley-on-Thames, and Wallingford. He has now written the memoir to accompany Sheet 284 of the new series Geological Surrey Map, which embraces an area concerning which we have hitherto had very little detailed information beyond that contained in previous official memoirs on more extensive tracts, by $H$. W. Bristow, W. Whitaker, and A. J. Jukes-Browne. The six-inch field-maps, showing the revised geology, with notes by the late J. H. Blake and Messrs. C. E. Hawkins and F. J. Bennett, were placed at the service of the author.

The country under consideration is almost wholly in Hampshire, the northern part including a tract of the Eocene strata of the London Basin; and the southern part consisting mainly of Chalk with a portion

1 Comptes Rendlss, 1904, rol. 138, p. 184. 